\title{
Prevention of Neurotrauma: An Evolving Matter
}

Neurotrauma is a multifaceted disease. In recent decades, the number of injuries caused by violence and accidents has increased. Cranioencephalic trauma is a major cause of death in developed countries. It is estimated that alone in the United States of America, about 100,000 people die annually, and among the survivors, there are a significant number of people with disabilities with significant costs to the health system. ${ }^{[1-3]}$ Cranioencephalic trauma is considered to be the injury of traumatic origin that occurs on the cranial vault and its contents. Traumatic brain injury is a major problem worldwide. It accounts for at least half of trauma-related deaths and impacts on the high costs for health systems, support for treatment, and rehabilitation of patients. In the United States, the costs are estimated at 60 billion dollars annually, whether direct or indirect for loss of labor productivity. Modern trauma response teams, new diagnostic aids, neurosurgical centers, and intensive care treatment have contributed to lower mortality rates for patients with traumatic brain injury, where available series in the literature report mortality of $20 \%-30 \%$ of patients. Despite these effective advantages, there are many aspects that should be improved with regard to the management of traumatic brain injury. ${ }^{[4,5]}$ 
In prevention of neurotrauma injuries, at this point, we need to define the categories of injury prevention, primary prevention is that which eliminates the event, secondary prevention decreases the effect, and tertiary prevention improves outcomes.

\section{New Epidemiological Findings}

Injuries associated with trauma are a silent epidemic. The field of violence prevention is still under development but has grown significantly in the recent decades. International discussions on violence prevention policies have been analyzed in scenarios such as the United Nations Assembly and specifically in the World Health Assembly, where all the health ministers of the member nations of the World Health Organization participate..$^{[6-8]}$

Cranioencephalic trauma is a major cause of death not only in middle- and low-income countries but also in high-income countries. In addition, it generates an important number of people with disabilities, which implies an important cost burden for health systems at a global level.

Multiple regulations have been imposed through national protection programs, among which are the establishment of speed limits, mandatory use of seat belts, reflective waistcoats, and helmets. In addition, it has been proposed to impose sanctions on drunk drivers and police control on roads and areas at high risk of accidents. These areas usually present conditions that can increase the risk of traffic accidents, such as limitation of visibility, deterioration of their structure, defects of flatness, lack of signaling, and sharp curves. ${ }^{[9]}$

The identification of areas of the greatest accident may contribute to the development of prevention programs led by governments and their road authorities. Knowledge about the magnitude and importance of prevention has increased markedly. It is important to promote knowledge of the categories in injury prevention, taking into account that primary prevention leads to the elimination of the causal event, secondary prevention decreases the effect, and tertiary prevention improves outcomes.

\section{Developing Neurotrauma Prevention Programs}

There are already clear examples of measures to reduce the severity of urban road accidents, especially from an early age, such as the "Think First" program, supported by the American Association of Neurological Surgeons and the Congress of Neurological Surgeons. Other similar programs, largely using social networks, have been applied in different regions of the world as part of national educational campaigns. Two examples of easy application include the "Mayo Amarillo" movement for the prevention of traffic accidents and the "Think Good" campaign, which was recently evaluated, by neurosurgery services in Brazil, including basic aspects such as presentation of readings and videos, distribution of educational pamphlets, design of graphic emblems of the campaign, distribution of T-shirts, and dissemination by mass media. ${ }^{[10-12]}$

At present, we have evidence that interventions such as home visiting, parent education, abusive head trauma prevention, and multicomponent program are useful in the prevention of trauma, especially in child abuse injuries.

With the implementation of neurotrauma prevention strategies, it could impact on the reduction of approximately 1.2 million deaths from traffic accidents that occur annually in the world, representing about 3000 deaths/day. Most of these deaths occur in low- and middle-income countries. The challenge is important and includes many aspects such as measuring prevention legislation in neurotrauma, strengthening educational programs, improving infrastructure in cities to protect the vulnerable user in the public highway, and finally, the creation of databases that systematically compile information to redirect prevention strategies. ${ }^{[13-16]}$

\section{Financial support and sponsorship}

Nil.

\section{Conflicts of interest}

There are no conflicts of interest.

Samer Hoz, Luis Rafael Moscote-Salazarl

Department of Neurosurgery, Neurosurgery Teaching Hospital, Baghdad, Iraq, ${ }^{1}$ Department of Neurosurgery, University of Cartagena, Colombia

Address for correspondence: Dr. Luis Rafael Moscote-Salazar, University of Cartagena, Colombia, USA. E-mail: mineurocirujano@aol.com

\section{REFERENCES}

1. Gordon JE. The epidemiology of accidents. Am J Public Health Nations Health 1949;39:504-15.

2. World Health Assembly. Child Injury Prevention. 64 $4^{\text {th }}$ WHA Resolution, 24 May, 2011. Available from: http://www.apps.who. int/gb/ebwha/pdf_files/WHA64/A64_R27-en.pdf?ua=1). [Last accessed on 2017 Aug 04].

3. Park E, Bell JD, Baker AJ. Traumatic brain injury: Can the consequences be stopped? CMAJ 2008;178:1163-70.

4. Rubiano AM, Puyana JC, Mock CN, Bullock MR, Adelson PD. Strengthening neurotrauma care systems in low and middle income countries. Brain Inj 2013;27:262-72.

5. Rubiano AM, Charry JD, Garzón-Cediel E. Brain Trauma Injury. In: Godoy D, Ugarte S, editor. Green Book Cuidado Intensivo. $1^{\text {st }}$ ed. Bogotá: Editorial Distribuna; 2014. p. 110-22. 
6. Volpe R, Lewko J, Batra A. A Compendium of Effective, Evidence Based Best Practices in Prevention of Neurotrauma. $1^{\text {st }}$ ed. Toronto: Education University of Toronto Press; 2002. p. $230-5$.

7. Orton E, Whitehead J, Mhizha-Murira J, Clarkson M, Watson MC, Mulvaney CA, et al. School-based education programmes for the prevention of unintentional injuries in children and young people. Cochrane Database of Systematic Reviews 2016, Issue 12. Art. No.: CD010246. DOI: 10.1002/14651858.CD010246.pub2.

8. Falavigna A, Medeiros GS, Canabarro CT, Barazzetti DO, Marcon G, Carneiro Monteiro GM, et al. How can we teach them about neurotrauma prevention? Prospective and randomized "Pense Bem-Caxias do Sul" study with multiple interventions in preteens and adolescents. J Neurosurg Pediatr 2014;14:94-100.

9. Quinlan KP, Brewer RD, Sleet DA, Dellinger AM. Characteristics of child passenger deaths and injuries involving drinking drivers. JAMA 2000;283:2249-52.

10. Sattin RW. Falls among older persons: A public health perspective. Annu Rev Public Health 1992;13:489-508.

11. Murray CJ, Lopez AD, editors. The Global Burden of Disease: A Comprehensive Assessment of Mortality and Disability from Diseases, Injuries, and Risk Factors in 1990 and Projected to 2020. Boston, MA: Harvard School of Public Health; 1996.

12. Roberts I, Mohan D, Abbasi K. War on the roads. BMJ 2002;324:1107-8.

13. Centers for Disease Control and Prevention (CDC). Motor-vehicle safety: A $20^{\text {th }}$ century public health achievement.
MMWR Morb Mortal Wkly Rep 1999;48:369-74.

14. Bener A, Abu-Zidan FM, Bensiali AK, Al-Mulla AA, Jadaan KS Strategy to improve road safety in developing countries. Saudi Med J 2003;24:603-8.

15. Rubiano AM. Strengthening neurotrauma care in the Pan American Region. J Trauma Crit Care Emerg Surg 2013;2:5-6.

16. Reilly P. The impact of neurotrauma on society: An international perspective. Prog Brain Res 2007;161:3-9.

This is an open access article distributed under the terms of the Creative Commons Attribution-NonCommercial-ShareAlike 3.0 License, which allows others to remix, tweak, and build upon the work non-commercially, as long as the author is credited and the new creations are licensed under the identical terms.

\begin{tabular}{|l|l|}
\hline \multicolumn{2}{|c|}{ Access this article online } \\
\hline Quick Response Code: & Website: \\
\hline
\end{tabular}

How to cite this article: Hoz S, Moscote-Salazar LR. Prevention of neurotrauma: An evolving matter. J Neurosci Rural Pract 2017;8:S141-3. 